\title{
Implications of geoarchaeological investigations for the contextualization of sacred landscapes in the Nile Delta
}

\author{
Eva Lange-Athinodorou \\ Lehrstuhl für Ägyptologie, Julius-Maximilians-Universität Würzburg, Würzburg, 97070, Germany \\ Correspondence: Eva Lange-Athinodorou (eva.lange@uni-wuerzburg.de)
}

Relevant dates: $\quad$ Received: 2 July 2020 - Revised: 30 September 2020 - Accepted: 9 October 2020 Published: 12 February 2021

How to cite:

Lange-Athinodorou, E.: Implications of geoarchaeological investigations for the contextualization of sacred landscapes in the Nile Delta, E\&G Quaternary Sci. J., 70, 73-82, https://doi.org/10.5194/egqsj70-73-2021, 2021.

Abstract:

Key elements of sacred landscapes of the Nile Delta were lakes, canals and artificial basins connected to temples, which were built on elevated terrain. In the case of temples of goddesses of an ambivalent, even dangerous, nature, i.e. lioness goddesses and all female deities who could appear as such, the purpose of sacred lakes and canals exceeded their function as a water resource for basic practical and religious needs. Their pleasing coolness was believed to calm the goddess' fiery nature, and during important religious festivals, the barques of the goddesses were rowed on those waters. As archaeological evidence was very rare in the past, the study of those sacred waters was mainly confined to textual sources. Recently applied geoarchaeological methods, however, have changed this situation dramatically: they allow in-depth investigations and reconstructions of these deltaic sacred landscapes. Exploring these newly available data, the paper presented here focuses on the sites of Buto, Sais and Bubastis, by investigating the characteristics of their sacred lakes, canals and marshes with respect to their hydrogeographical and geomorphological context and to their role in ancient Egyptian religion and mythology as well.

Kurzfassung: Heilige Gewässer verschiedener Art, d.h. Seen, Kanäle und künstliche Becken, verbunden mit auf erhöhtem Gelände befindlichen Tempelgebäuden, sind als Schlüsselelemente sakraler Landschaften des Nildeltas anzusehen. Im Falle von Tempeln von Göttinnen ambivalenter, ja gefährlicher Natur, wie Löwengöttinnen und allen anderen weiblichen Gottheiten, die als solche erscheinen konnten, ging die Funktion heiliger Seen und Kanäle über ihren Zweck als Wasserressource für grundlegende praktische und religiöse Bedürfnisse hinaus. Man glaubte, dass ihre angenehme Kühle die feurige Natur der Göttin beruhigte; auf den Gewässern fuhren auch die heiligen Barken, in denen die Göttinnen bei wichtigen religiösen Festen gerudert wurden. Da man bis vor relativ kurzer Zeit kaum über archäologische Belege verfügte, beschränkte sich das Studium dieser heiligen Gewässer hauptsächlich auf Textquellen. Die in neuerer Zeit verstärkt angewandten geoarchäologischen Methoden haben diese Situation jedoch dramatisch verändert und ermöglichen nun eingehende Untersuchungen und Rekonstruktionen dieser heiligen Landschaften des Nildeltas. Unter Einbeziehung dieser neu verfügbaren Daten konzentriert sich die hier vorgelegte Arbeit auf die heilige Landschaft von Buto, Sais und Bubastis, indem sie die Merkmale ihrer heiligen Seen, Kanäle und Sümpfe im Hinblick auf ihren 
hydrogeographischen und geomorphologischen Kontext sowie auf ihre Rolle in der altägyptischen Religion und Mythologie untersucht.

\section{Introduction}

Investigations of sacred landscapes occur at the very intersection of geomorphology and archaeology, where the methods and aims of both disciplines truly come together. The recent increase in geoarchaeological studies at several sites in the Nile Delta allows the reconstruction of important features of their respective palaeo-landscapes. In archaeology, the investigation of landscapes and their impact on human cultural history is well established (David and Thomas, 2016; on the different concepts of landscape in geoarchaeology cf. also Cordoba, 2020, p. 50).

The study of sacred landscapes represents a special branch of landscape archaeology, since sacred landscapes are essentially landscapes that are marked and mapped with mythological references and explanations. They were sometimes changed due to human activities or by additions of human material culture. In Egyptology, the term "sacred landscape" is oftentimes used for temple complexes and their nearby surroundings. Sometimes also waterways or land routes come into play, as they could connect two or more temples, thus widening the sacred landscape. For important Egyptian religious celebrations such as the so-called Opet festival as a well-known example, it was essential that the cult image of the god Amun travelled on his sacred barque from his main temple at Karnak to Luxor around $3 \mathrm{~km}$ to the south (Darnell, 2010). These travels took place on natural as well as on artificial waterways and land routes. These were the Nile and the canals connecting the temples to their surroundings and also their paved stone paths (dromoi) leading to their entrances (Geßler-Löhr, 1983, pp. 144-145; Boreik et al., 2017). Here and elsewhere, we can observe a most interesting process: at first, existing natural topographical features were exploited to conduct religious ceremonies. Subsequently, their requirements could then initiate the addition of artificial structures and perhaps even the changing of the natural landscape.

Turning now from the Nile Valley to the Nile Delta, what were the main constituents of a sacred landscape there? In the delta, temples and cemeteries were set on top of natural elevations (van den Brink, 1986, p. 12). In the eastern delta, these were the remains of deeply eroded massive Pleistocene sediments, accumulated by the vigorous Pre-Nile, the so-called geziras (Said, 1981, 1993). In the western delta, temples were built on elevations as well, which seem to be the result of different geomorphological processes, as became clear in the case of Buto (Wunderlich, 1989). Regardless of their geomorphological origin, geziras were the dominant feature of the vast alluvial plain of the delta. Other distinctive characteristics of this landscape were the mani- fold watercourses and marshlands with their stagnant waters. Therefore, a body of water, whether in the shape of a stream, canal, lake or pool, connected to an elevated temple formed the basic elements of a deltaic sacred landscape.

In the past, knowledge of the existence of sacred lakes or canals attached to or surrounding temple buildings was mainly based on religious texts with little additional archaeological evidence. The previously available record pointed to the existence of deltaic sacred landscapes at a number of sites. Of them, Buto (Geßler-Löhr, 1983, pp. 403-404) and Sais (Geßler-Löhr, 1983, pp. 233-240; Wilson, 2006, 2019 , pp. 5, 17) in the western delta, Busiris in the central delta (Geßler-Löhr, 1983, pp. 437-438), and Tanis (Montet, 1966; Leclère, 2008, pp. 442-443) and Bubastis (LangeAthinodorou et al., 2019) in the eastern delta were especially well known. At any rate, comparative studies of sacred lakes are still rare (Yoyotte, 1962; Sauneron, 1964; Geßler-Löhr, 1983; Tillier, 2010); in particular, studies on sacred lakes as elements of deltaic sacred landscapes do not exist at all.

Nowadays, evidence comes from a much wider variety of sources. In addition to textual and archaeological records, we have access to results of sedimentological analysis from core drillings, as well as from geoelectric and geomagnetic investigations. These now allow the investigation of the location, shape or course of sacred waters at temple sites. To date however, such comprehensive, multi-methodological approaches have only been applied to a relatively small number of delta sites with well-known large-temple districts. At present, Buto, Sais and Bubastis are the main sites that provide us with sufficient textual, archaeological and geoarchaeological material for a comparative analysis. Therefore, they represent the topics of the following case study, which will focus on the landscape surrounding the large temples of these cities. Moreover, the local main deities of these cities all belonged to the canon of the so-called dangerous goddesses; i.e. they all shared specific qualities, which influenced certain elements of their cults, temple buildings and their surroundings as well.

\section{Buto}

At Buto in the northwestern delta the sacred landscape refers to the temple of the goddess Wadjet, the main deity of the city, who also embodied the red crown of Lower Egypt. In this capacity, Wadjet was the northern counterpart to the goddess Nekhbet, the goddess of the white crown of Upper Egypt (Leclère, 2008, p. 198, remark no. 5). 


\subsection{Textual sources}

A statue dating to the Middle Kingdom from Meidum mentions the goddess Wadjet with the epithet "lady of the Isheru" (Geßler-Löhr, 1983, p. 403). The Egyptian term Isheru usually designates horseshoe-shaped lakes or canals connected to or surrounding temples of goddesses, who were believed to display not only benevolent but also dangerous qualities (Sauneron, 1964, pp. 50-57; Geßler-Löhr, 1983, pp. 47, 401). To capture this ambivalent character, these Egyptian goddesses were imagined to appear as lionesses, primarily Sekhmet, Bastet, Shesemtet and other genuinely feline goddesses. In addition others, e.g. Hathor, Mut, Neith, Nekhbet and Wadjet, who usually appeared in a different, either anthropomorphic or zoomorphic, form (Tillier, 2010, pp. 167, 171-172; Lange-Athinodorou, 2019, pp. 554-561, 580-581) could also be imagined as lionesses. According to their predatory nature, lionesses were feared as wild and fiery. Possibly based on wildlife observations at natural water places were lions would rest, canals or lakes close to temples of lioness goddesses were believed to please the goddesses' wild nature. Therefore, locations surrounded by lakes or canals were considered the ideal setting for their cult.

Still, that the inscription on the above-mentioned statue really referred to a sacred lake or canal of the temple of Wadjet at Buto is not beyond all doubt. The reason for that uncertainty is that several temples all over Egypt had lakes called Isheru where Wadjet and other goddesses obtained subsidiary cults. The most famous Isheru lake was the horseshoe-shaped one at the temple of Mut at Karnak. However, the earliest attestations of the Isheru of the temple of Mut at Karnak date back to the 18th dynasty (ca. 1460 BCE). They are therefore much younger than the earliest records of the term Isheru (Yoyotte, 1962, pp. 101-103, 106; GeßlerLöhr, 1983, p. 412); one proof comes from a list of deities of Egypt receiving offerings from the king. Each deity is not only listed by name but also further specified by its cult place. There, the lioness goddess Sekhmet bears the epithet "Sekhmet in Isheru", with the name of the sacred water used as a toponym of its own (Mariette, 1869, T. I. Pl. 44.9). As the text comes from the temple of Seti I at Abydos one would date it to the New Kingdom (19th dynasty, ca. 1280 BCE). However, Yoyotte (1962) and Sauneron (1964) argue that the list is actually a copy from a much older template of the late Old Kingdom (6th dynasty, ca. 2260 BCE; Yoyotte, 1962, p. 105; Sauneron, 1964, p. 56.4; also Geßler-Löhr, 1983, p. 402). In addition, a block from the temple of Min at Koptos depicts Sesostris I (12th dynasty, 1919-1875 BCE) in front of the lioness goddess Bastet with the caption "Bastet, lady of the Isheru". Here, the use of the settlement determinative in the writing shows again that this name was used as a toponym, yet its exact location remains unknown (Petrie, 1896, Pl. X.2; Geßler-Löhr, 1983, p. 404; Gomàa, 1987, p. 209). In the light of this unique evidence, it remains impossible to decide where the Isheru from the inscription on the statue from
Meidum was located (cf. Yoyotte, 1962, pp. 99-101; GeßlerLöhr, 1983, p. 403; was it Memphis or Meidum?).

Specific information about sacred waters of the temple of Wadjet at Buto comes from an inscription at the temple of Mut at Karnak from the Ptolemaic Period (second-first century BCE). The text tells the story of an assemblage of the deities of Egypt at Buto where the gods and goddesses of the Ennead are ordered to dig out a canal for Wadjet: "the gods of the Ennead, as follows: 'you shall travel to the hill-country of Buto ... were you shall dig out a canal for the mighty one. You shall draw its water with both of your hands [so?] her [temple?] is encircled by its canal because she is content in the great primeval ocean"' (Geßler-Löhr, 1983, p. 403; Sauneron, 1983, p. 20, Taf. X.11-13).

The Greek historian Herodotus (ca. 450 BCE) describes a lake at this temple: "In this way the shrine is for me the most marvellous of all things to see in this temple; the second place has an island called Chemmis. This lies in a deep and wide lake close to the temple at Buto, and the Egyptians say that it floats" (Hd. II. 156.1; Wilson, 2015, p. 221; Nesselrath, 2017, p. 194).

Thus the essential information provided by the texts is as follows:

1. There was a canal at the temple(?) of Wadjet at Buto in order to pacify her dangerous temper.

2. There was also a lake close to the temple with a floating vegetated island called Chemmis.

Chemmis is the Greek term for the Egyptian toponym Akhbit - "papyrus thicket of the bee", with "bee" as the heraldic animal designating the geographical area of the delta. Akhbit is well known from written sources, mostly of a mythological and religious background from the time of the Pyramid Texts (ca. $2350 \mathrm{BCE}$ ) onwards. There, it means the hiding place of the goddess Isis where she raised her infant son and crown prince Horus, in order to keep the god Seth, Horus' murderous uncle, from harming him. Gardiner (1944), who investigated all available textual references, discussed the possibility that the toponym Akhbit was used to designate not one but two different locations: the first site was an Akhbit in the temple district of Buto, as mentioned by Herodotus. This was probably an artificial replica of the mythological hideout of the young god Horus in the papyrus marshes, designed as a vegetated island set in a sacred lake. On the other hand, according to textual evidence that treats Akhbit as a real locality and not as a specific element within the temple precinct, the second was a natural landscape area with papyrus marshes, which inspired the mythos. However, this Akhbit would have to be localized in the vicinity of Buto as well (Gardiner, 1944, pp. 53-58).

\subsection{Geoarchaeology}

At Buto, the temple of Wadjet was located at the northeastern Kom B (Hartung et al., 2009, p. 184). In fact, not much 


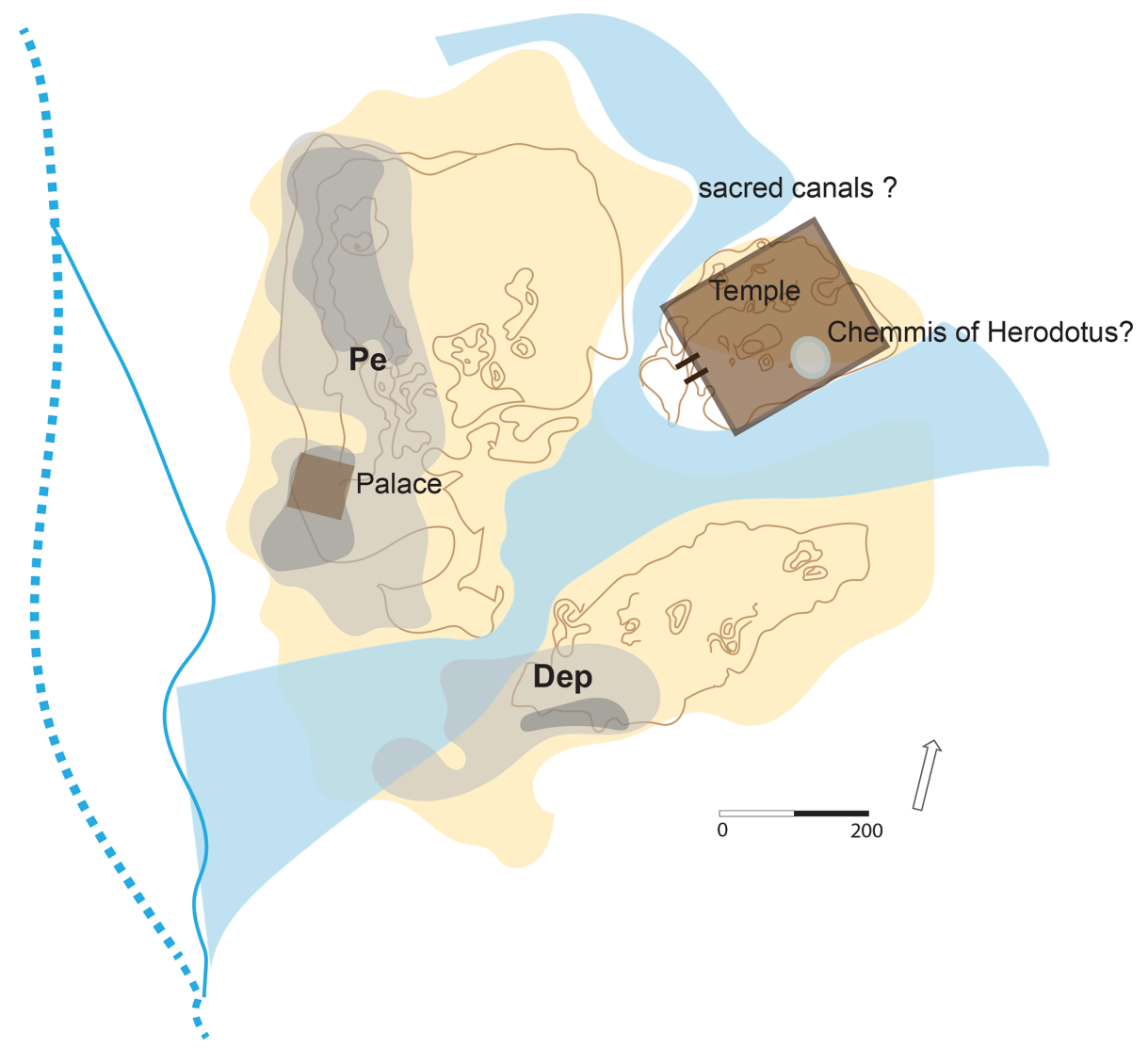

Figure 1. Topographic model of Buto with hypothetic course of the local canals at the temple. Topographic model after Hartung (2018, p. 102, Fig. 1).

survived of this building. Apparently, an enclosure wall of mud bricks of ca. $300 \mathrm{~m}$ by $200 \mathrm{~m}$ encircled the temple in the Late Dynastic Period. Its main entrance was on its western side (von der Way, 1999, p. 184; Leclère, 2008, pp. 205208). Test trenches and drillings indicate the construction of a foundation made of sand in the Saite Period (seventh-sixth century BCE; Faltings et al., 2000, pp. 162-165). However, when looking at the elevation model of Buto (Hartung et al., 2009, p. 174, Abb. 27), a prominent depression between the northeastern, northwestern and southern parts of the tell, i.e. Kom A, B and C, is noticeable. One could speculate if this almost horseshoe-shaped depression could have formed a natural Isheru, presumably during the time of the inundation, when depressions were probably water-bearing.

At any case, a definitive answer could only be expected from the analysis of sediments of cores taken in that area. Although Hartung et al. (2009, p. 174, Abb. 27) conducted extensive drilling campaigns at the site, they focused mainly on the western stretch of the tell, leaving the area in question still unexplored. Interestingly, a single core drilling conducted by Faltings et al. (2000, pp. 167-168) in the eastern part of the temple precinct revealed green-greyish clayey mud with organic remains of plants, shells and fish bones, providing evi- dence of the former existence of a stagnant water body in this area.

Still ongoing is a long-term research programme on the natural landscape of the wider area around Buto. Based on core drillings and the digital and visual analysis of satellite imagery, Wunderlich (1989) detected massive peat layers to the north of Buto as far as Lake Burullus, indicating the former existence of a vast swampy area. These swamps originated from a belt of semi-marine lagoons, resulting from the marine transgression after the end of the last glacial period.

Figure 2 shows the extension of the consolidated gezira sands on which the settlement of Buto was founded and to its north the size and limits of the peat horizon to the north as attested by core drillings conducted by Wunderlich (1989). The peat horizon is the remnant of the above-mentioned semimarine lagoon. C-14 datings on a number of test samples from the peat horizon (location indicated in Fig. 2) show that the lagoon belt moved inland to up to around $2 \mathrm{~km}$ north of Buto from 5050 to $4050 \mathrm{BCE}$. With the lowering of the sea level, the swamp dried up again from the fourth millennium BCE onwards (Wunderlich, 1989, pp. 106-110; Wunderlich and Ginau, 2014/2015, pp. 488-494).

Therefore, at the time of the beginning of the settlement at Buto in the second half of the fourth millennium BCE (Falt- 


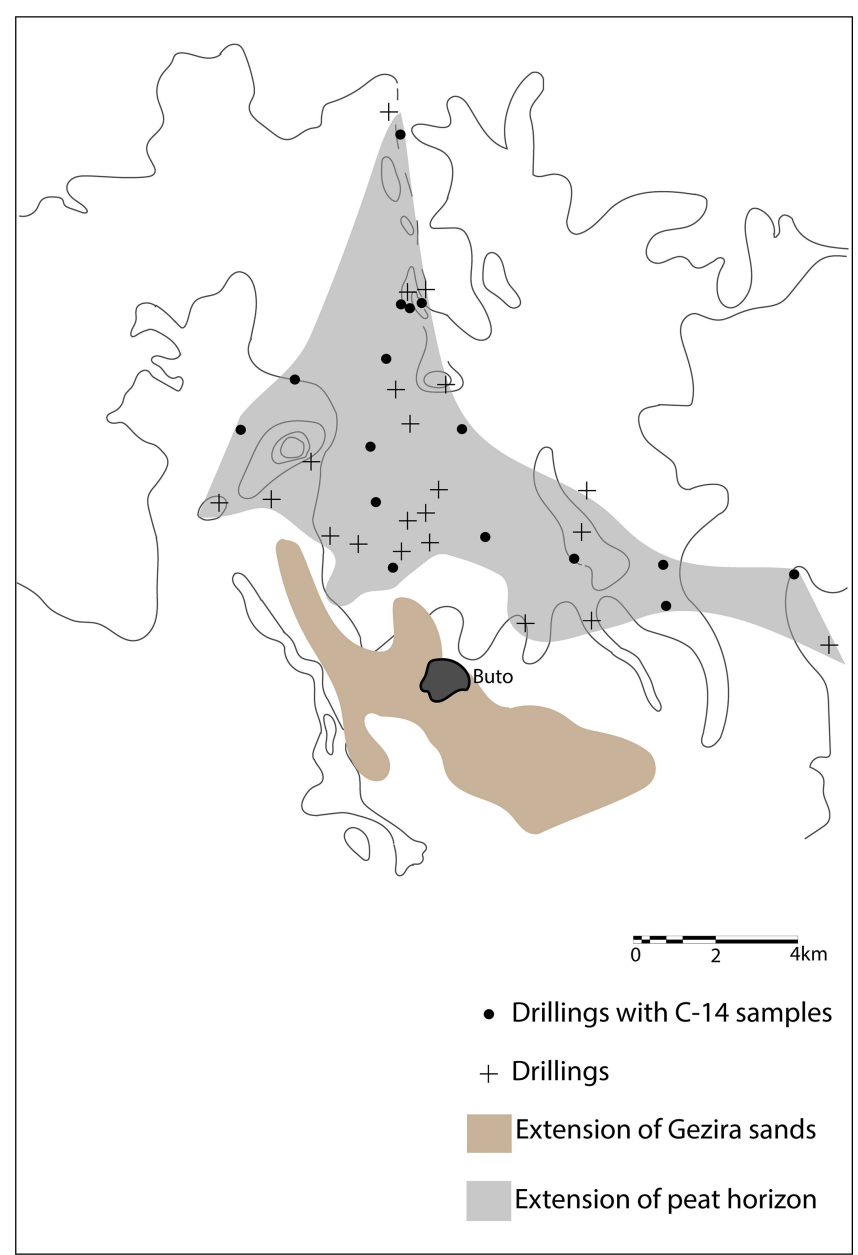

Figure 2. Geomorphology of Buto according to geophysical investigations, by courtesy of Jürgen Wunderlich (altered after Wunderlich, 1989, p. 108, Abb. 33).

ings, 1998, p. 373), the occupants of Buto could still explore large areas with open water surfaces and a dense vegetation of papyrus and other helophytes. Such a natural landscape would certainly match with the idea of the mythological papyrus marshes.

\section{Sais}

Sais was the main cult place of the goddess Neith, a goddess of deltaic origins (Wilson, 2006, pp. 2-3; Wilson, 2011, pp. 186-187), who since the earliest times belonged to the most important female deities of Egypt. As stated above, besides her anthropomorphic image often wearing the red crown of Lower Egypt, Neith could appear in the shape of a fearsome lioness goddess, sometimes associated with Sekhmet and Bastet (El-Sayed, 1982, p. 136).

\subsection{Textual sources}

Some important information concerning a lake at the temple of Neith at Sais under the reign of Amasis (570-526 BCE) comes from a biographical inscription on the dorsal pillar of the statue of an official named Horkhebi who states: "I dug a lake on the eastern side of the canal $w w$. [Its] length: 68 cubits, width: 65[?] cubits, lined with stone, with 8 staircases and walls around it $[\ldots]$ in it for Neith and the gods of the nome of Sais by order of the Dual king Amasis, son of Neith" (Geßler-Löhr, 1983, pp. 233-235).

The inscription on the statue of a woman from the early Ptolemaic Period usually cited in the literature amongst the textual evidence (Leclant and De Meulenaere, 1957, p. 36; Geßler-Löhr, 1983, p. 237; Zecchi, 1996, pp. 32-33; Wilson, 2019 , p. 17) should be omitted as the reading of the group of signs in question is unsure and might refer to the offerings rather than to the lake. ${ }^{1}$

Herodotus describes the lake of the temple at Sais as follows: "Great stone obelisks stand in this sacred precinct, and a lake adjoins, beautifully lined with a crepidoma of stone all around; it is, as it seemed to me, as big as the lake at Delos, the so-called Circular Pond" (Hd. II. 170; Wilson, 2015, p. 228; Nesselrath, 2017, p. 200; also Wilson 2006, pp. 3637).

These texts bear witness to the existence of a sacred lake in the precinct of the temple of Neith at Sais. The biographical inscription of Horkhebi provides some details on the dimensions and the location of the lake, which will be discussed below (Sects. 3.2 and 4 ).

\subsection{Geoarchaeology}

Similar to Buto, Sais was originally a twin tell, with the settlement started on two neighbouring geziras, to the west and east of a natural canal that evolved out of a lake between the two elevations (Wilson, 2006, pp. 203-204).

According to the drillings conducted by the team of Wilson (2006), an ancient water canal once flowed close to the eastern side of the so-called northern enclosure, an area to the north of the site. In this area to the north of the site was once located the temple of Sais, now completely destroyed. There might have been another palaeo-canal to the east, yet the traces found there indicate a more recent dating for this waterway (Wilson, 2006, pp. 177-204, 252-256).

On the eastern side of the northern enclosure, a possibly natural spring still flows. It may have already existed in ancient times. Wilson (2006) also reports the discovery of several limestone blocks at the site of this spring, which might have belonged to the lining of the sacred lake. According to her the spring could have been the source of the sacred lake of the temple (Wilson, 2006, p. 256). This fits well with the biographical text of Horkhebi cited above, who describes the

\footnotetext{
${ }^{1}$ My thanks go to Karl Jansen-Winkeln for his helpful comments on this text.
} 


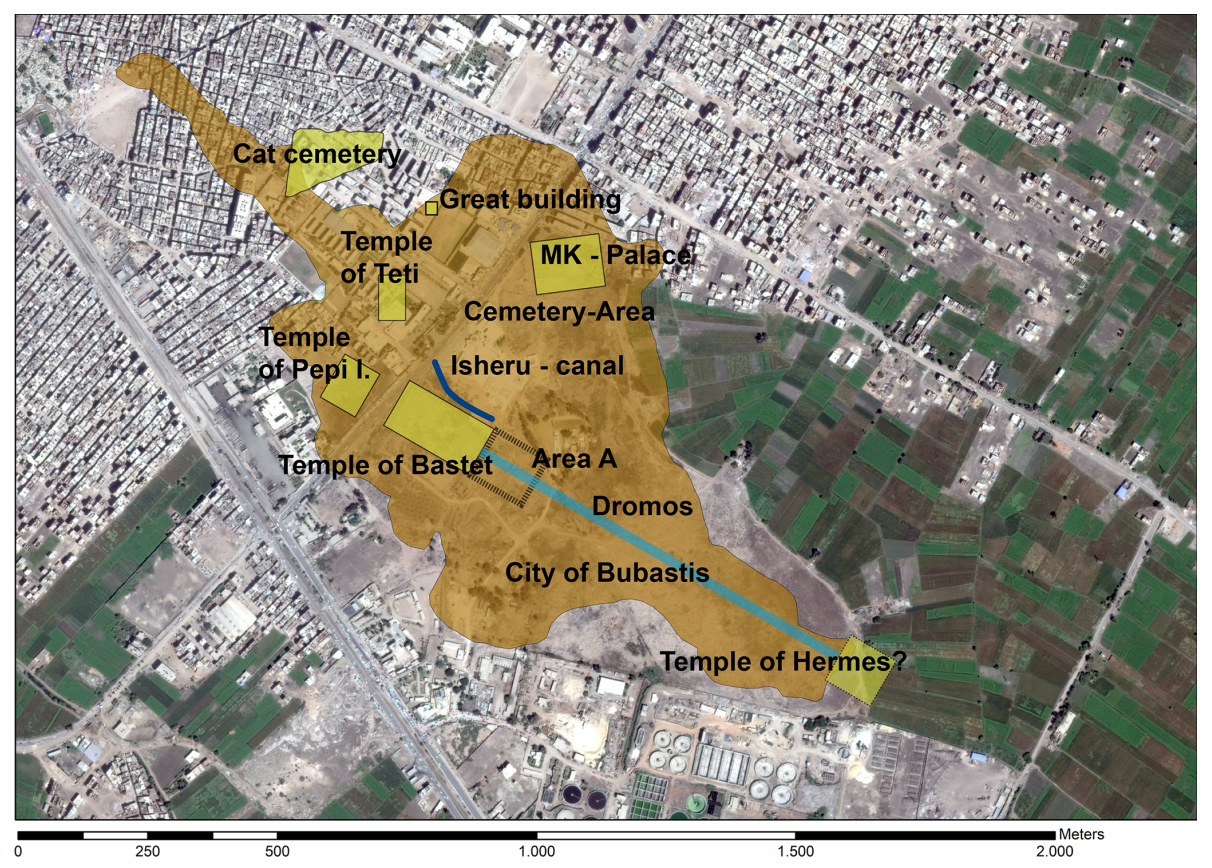

Figure 3. The course of the northern sacred canal at Bubastis according to the latest geophysical investigations. (C) Google Maps, modified by Eva Lange-Athinodorou.

construction of a sacred lake at the temple, more precisely an artificial water basin, lined with stone blocks and accessible via staircases leading down to the water.

\section{Bubastis}

Attestations for the cult of Bastet date back to the second dynasty (ca. $2850 \mathrm{BCE}$ ). If Bubastis was already the main cult place of this goddess in these early times is difficult to establish, as the earliest evidence of the cult of Bastet there dates back to the sixth dynasty only (Lange, 2016, pp. 310313). We have, however, ample textual and archaeological evidence that she was the main goddess of Bubastis from then on until the time of the Roman emperors (Naville, 1891; de Wit, 1956, pp. 292-297 ).

\subsection{Textual sources}

The sacred waters of Bubastis appear prominently in the written record. Papyrus Brooklyn 47.218.84, a mythological compendium on the cities of the delta from the second part of the seventh century BCE, contains two references to it. The first says about the goddess, "She is on the pedestal of 'throwing down the enemies'. A falcon tames her, two hippo deities surround her, an Henet water is all around her, the length of which is ... 7(?) (cubits and the width) 42 (cubits)" (pBrooklyn 47.218.84, IX.4; Meeks, 2006, p. 20). The term Henet that refers to the waters surrounding the temple of Bastet can generally designate various types of natural bodies of water, such as Nile branches, canals and lakes (Yoyotte, 1962, p. 88.4; Geßler-Löhr, 1983, p. 407, footnote 1348; Meeks, 2006, pp. 100-101).

Another paragraph in the same papyrus calling those waters Isheru informs us about the triumphal appearance of Bastet as the defeater of Seth in her sacred barque during her annual festival: "And they row her in the Oryx antelope on the Isheru at the moment as she saved the Udjat-Eye from him". (pBrooklyn 47.218.84, IX.7-8; Meeks, 2006, p. 20; Bohms, 2013, pp. 36-42). A very vivid depiction of this scene appears on the fragment of a stela from the Late Period. It was discovered at Bubastis at the cemetery of the cats, the sacred animals of the goddess (El-Sawi, 1977). Here we find all the elements described in the papyrus: the statue of the goddess in her shrine sitting in a barque, the stern of which is shaped like the head of an oryx antelope, the animal of Seth, representing the enemy she had subdued. Under the barque, zigzag lines indicate the water of the sacred canal as well (cf. also Geßler-Löhr, 1983, p. 407 and Fig. 74; Schorsch, 2015).

Herodotus describes the environments of the temple of Bastet at Bubastis in detail: "Except the entrance, the rest is an island. The canals, which come from the Nile, are not joining one another, but each one extends to the entrance of the temple; the one surrounds the one side, the other the other side and each one is 100 feet wide and shadowed by trees" (Hd. II. 138.1; Wilson, 2015, pp. 208-209; Nesselrath, 2017, p. 184).

The above-mentioned texts all come from the second part of the first millennium BCE. Still, how far the Isheru at Bubastis really dates back is unclear. The above-mentioned 
relief block (cf. Sect. 1.1) from the early 12th dynasty from Koptos names Bastet as the Lady of Isheru. Yet, the location of the Isheru mentioned on this block does not necessarily have to be at Bubastis, contrary to some attempts to locate it there (Sauneron, 1964, pp. 52, footnote 33; Yoyotte, 1962, pp. 103-104).

\subsection{Geoarchaeology}

Core drillings at Bubastis conducted by Ullmann et al. (2019, pp. 190, 195-197) revealed that the temple of Bastet sits on the elevated part of a NW-SE-oriented gezira of Pleistocene origin. Furthermore, it is possible that Bubastis, like Buto and Sais, was actually built not only on one elevation but also on a twin tell. In that case, the temple area was located on the southern mound, while the cemeteries were established at the northern one.

Recently, DCR soundings and ERT by Amr Abd el-Raouf pointed to the existence of a canal, close to the temple of Bastet. Core drillings and sediment analyses by Julia Meister corroborated those finds, placing a canal around $50-60 \mathrm{~m}$ to the north of the outer wall of the temple (Lange-Athinodorou et al., 2019). The results of the combined geophysical analysis led to the detection of around a $300 \mathrm{~m}$ length of a canal, its width measuring between 20 and $30 \mathrm{~m}$ (cf. Fig. 3; LangeAthinodorou et al., 2019). This canal was most probably the northern part of the canal system that surrounded the temple, namely the Isheru or Henet of the Egyptian texts.

The dominant infill of the canal with fine-grained sediments as well as their high content of organic matter indicates that very slowly flowing water accumulated them. Parallel sediment laminations point to a periodic influx of fresh water, coming from a larger river, possibly a nearby Nile tributary. Eventually, the canal at the temple was cut off and became stagnant water, gradually silting up (Lange-Athinodorou et al., 2019, pp. 6-8, 11). A dating of the canal and its active periods is still difficult and must await further chronological analysis. However, the textual sources show that the canal system was existent at least in the time from the seventh to the fifth century BCE.

\section{Discussion}

The survey of the textual and geoarchaeological evidence represented in Sects. 1.1-3.2 allows some tentative reconstructions and comparisons of the lakes and canals in, around and nearby the temples of Buto, Sais and Bubastis with respect to their different hydrogeographic and geomorphological contexts. In addition, I will discuss the question as to whether the canals and lakes at those sites are of a natural or artificial origin.

For Buto, a text from the Ptolemaic Period at Karnak points to the existence of a sacred canal around the temple. By contrast, Herodotus refers to a "deep and wide" lake with an island somewhere close to the temple (cf. Sect. 1.1).
As one can see in the case of Bubastis, Herodotus did differentiate between lakes and canals thoroughly. Therefore, the two texts might actually describe two distinct sacred waters at Buto: a probably horseshoe-shaped canal surrounding the temple mound and a lake within the temple enclosure wall. A drilling core in the eastern part of the temenos, south of the main axis of the temple, indicates that the sacred lake could have been somewhere in this area (cf. above Sect. 1.2). However, without further core drillings there is no way of determining its dimensions. Furthermore, no core drillings, sediment analyses and geoelectric soundings are available yet from the depression around the temple mound, where the canal of Wadjet could have flowed as described in the Ptolemaic text. Its existence in that vicinity is definitely a hypothesis worth testing by the means of geoarchaeological methods in the future. Another interesting, yet admittedly still unproven, possibility is that the palaeo-landscape with large marshlands to the north of Buto, as revealed by the geophysical survey there (cf. Sect. 2.1), might have inspired the mythos of the hiding of the child god Horus by his mother Isis in the papyrus thickets. In this process, the natural landscape, i.e. the marshlands called Akhbit, would have undergone a mythological interpretation and could later on be used as an ideal model providing the scenery for this specific mythos in Egyptian religious texts.

At Sais, we encounter a different situation. The texts unanimously describe a sacred lake, which Herodotus reports was established within the temenos area. The earlier text of Horkhebi adds its dimensions: the basin he built would have measured $35.63 \mathrm{~m}$ by $34.06 \mathrm{~m}$, thus forming an almost square structure. Measuring $100 \mathrm{~m}$ by $70 \mathrm{~m}$, the lake at Delos, which Herodotus uses for comparison, was, however, much larger (Nesselrath, 2017, p. 788, no. 264).

More complicated is the localization of the lake with regards to the canal of the name $w w$ in Horkhebi's inscription. At first glance, one is inclined to identify this waterway with the palaeo-canal to the east of the temple area (cf. Sect. 2.2). Yet, as Wilson (2006, p. 257) points out, this poses problems, because Horkhebi clearly states, "I dug a lake on the eastern side of the canal $w w$ " (emphasis added). The eastern side of the palaeo-canal is far outside of the temenos area. In this case, the artificial lake would have been nowhere within the enclosure wall of the temple, which seems to be very improbable. Moreover, the position of the spring, as the possible source of the lake, can be localized to the west of the palaeo-canal and hence doubtless well within the temple district (Wilson, 2006, p. 262, Fig. 8). Therefore, the $w w$ canal should not be identified with the palaeo-canal to the east detected by core drillings. Rather, the $w w$ canal was probably flowing somewhere to the west of the northern enclosure. The canal detected in this area is however a more recent structure.

More evidence is available for Bubastis: the main sacred body of water of the temple was doubtlessly a structure of two canals coming from a Nile branch. The temple mound therefore must truly have given the impression of an is- 
land, quite as Herodotus described it. As was shown above (Sect. 3.2), one of the paragraphs of Papyrus Brooklyn provides information on its dimensions: "an Henet water is all around her, the length of which is ... 7(?) (cubits and the width) 42 (cubits)." Unfortunately, the first specification in the papyrus is illegible. The width of the canal given by the ancient texts on the other hand is very close to the facts discovered by the geophysical analysis: the 42 cubits of Papyrus Brooklyn are a little more than $22 \mathrm{~m}$. The description of Herodotus states $30 \mathrm{~m}$ for the width instead. These different statements of the dimensions in Papyrus Brooklyn and Herodotus might be explained by the fact that the canal was part of a dynamic hydrographic system. Its water level and dimensions therefore changed not only from season to season with the changing water volume of the Nile and its distributaries but also on a long-term scale. In Bubastis, another artificial basin might have also existed within the temple enclosure such as in Buto and Sais, but to date, there is no indication of it.

Finally, the question arises as to whether the sacred canals and lakes at Buto, Sais and Bubastis were of natural or artificial origin. In the case of the canals at Bubastis, the results of the geoarchaeological investigation do not yet allow a definitive answer. It is, however, conceivable that the natural hydrogeographic situation with two canals surrounding the elevated part of the gezira led to the founding of the temple of Bastet there. The main reasons for choosing this position were very probably the specific requirements of the cult of the lioness goddess (cf. Sect. 5; also Yoyotte, 1962, pp. 108109). In later times, people might have artificially maintained the function of the canal as a navigable waterway by digging out accumulating sediments on a more or less regular basis. Regarding the canal around the temple mound at Buto, a similar situation is imaginable but awaits future investigations as well. The temple lake at Sais might have been based on a comparable process of enhancing a natural situation by artificial means: assumedly, a natural spring in the western part of the temenos area was the source of water that filled an artificial basin built of limestone blocks. Finally, whether the sacred lake within the temple of Wadjet was in any way similar to the one at Sais cannot be answered without further data.

The question remains around which reasons might have caused the specific connection of the horseshoe-shaped lakes and canals and the temples of goddesses. One answer lies in the geomorphological situation of the temple sites in the delta. Here, temples were built on elevations, while the depressions close to them would be at least seasonally waterbearing. In that case, a half-circular shape of the pool or canal would emerge as in the cases of Buto and Bubastis. As horseshoe-shaped lakes were preferred near temples of goddesses in the Nile Valley as well, several scholars argue that their natural prototypes might have been temporary fan-shaped lakes evolving on the estuaries of the wadis after seasonal rainfall. Such temporary lakes provided water for a variety of wildlife and therefore also attracted hunting lion prides (Tillier, 2010, p. 173, footnote 46). People would observe lionesses at those natural lakes not only hunting but also lovingly caring for their cubs. By analogy, people might have imagined that this kind of landscape was favourable for lioness goddesses as well. The water surrounding their temples would cool and calm their temper and bring out their positive, caring and protective nature. Therefore, locations surrounded by lakes or canals would have been thought to have been the ideal setting for their cult.

According to the narration of Herodotus, countless people celebrated festivals at Bubastis in honour of Bastet, which seem to have been ecstatic and orgiastic. The celebrations involved drunkenness and displays of many kinds of ecstatic activities like wild dancing and singing (Hd. II. 59.160.1; Wilson, 2015, pp. 161-162; Nesselrath, 2017, pp. 144145). The already cited texts of Papyrus Brooklyn include a tale about Bastet, who saved the eye of Horus from Seth at Bubastis and was rowed on the sacred canals displaying her triumph over the enemy (cf. Sect. 3.1). This is actually the description of a river procession with a cult statue of Bastet in her barque shrine as the culmination of the festival. Surely, the appearance of the triumphant goddess would be the summit of a celebration passionately attended by the thousands of pilgrims who journeyed to her city every year to attend her festival.

\section{Summary and conclusions}

Elemental components of sacred landscapes at Buto, Sais and Bubastis were the canals and lakes in close proximity to the temples of the goddesses who were venerated in those cities. Geoarchaeological investigations not only bear witness to their existence but also indicate their dimensions and locations and help to reconstruct the hydrogeography and palaeolandscape they were connected to. So far, the analysis of the data gained by geoarchaeological methods leads to interesting results on the specifics of the lakes and canals at the three sites used as case studies: a sacred canal of the Isheru type and a sacred lake within the temple enclosure most probably defined the sacred landscape of Buto. At Sais, an existing sacred lake of possibly natural origin was enhanced for continuous use with an enclosure of stone blocks. The large Isheru-type canals of Bubastis enclosed the temple almost completely.

On the other hand, textual records are useful with regard to the understanding and reconstruction of the importance of sacred waters in the cult and the local mythology of Wadjet, Neith and Bastet. All of them were goddesses considered to be of an ambivalent nature: mighty, protecting and dangerous, the latter preferably to the enemies of the king; yet the rage of the goddesses could turn against even their admirers at any moment or, alternatively, into a peaceful calm temper (Lange-Athinodorou et al., 2019, pp. 554-561, 580-581). A 
canal system enclosing their temple or at least a lake close to the sanctuary was believed to be necessary to cool and please their unpredictable fiery temper.

Furthermore, the sacred canals were not only a tool to please and cool the mood of the goddesses; they were also a key element in the performance of their cults. The rich textual and pictorial evidence at Bubastis could be used as a role model of the events taking place on and around the sacred waters of Buto and Sais. Although there is no comparable textual evidence, it is well imaginable that Wadjet and Neith had festivals of their own with their barques appearing on their sacred canals and lakes during religious festivals. We know of such ceremonies at the temples of Sekhmet at Memphis, Mut at Karnak and Hathor at Dendera to name but a few (Geßler-Löhr, 1983, pp. 401-424; Tillier, 2010, pp. 170171).

The results of the geophysical survey of the environs of Buto now widen the horizon much further. The evidence of a large palaeo-swamp north of Buto leads to the question as to whether human experience of this impressive landscape resulted in the concept of the papyrus marshes of Akhbit as the hiding place of Horus, a centrepiece of Egyptian mythology. If correct, this could highlight the cognitive process of connecting natural landscapes with mythological narratives: certain features of natural landscapes of the delta, even far from temple buildings, were incorporated into the imaginary sacred landscapes of the delta in ancient Egyptian minds.

Data availability. All relevant data and references are cited in this article.

Competing interests. The author declares that there is no conflict of interest.

Special issue statement. This article is part of the special issue "Geoarchaeology of the Nile Delta". It is a result of the workshop "Geoarchaeology of the Nile Delta: Current Research and Future Prospects”, Würzburg, Germany, 29-30 November 2019.

Acknowledgements. I would like to thank the participants of the workshop for an interesting discussion, as well as the anonymous reviewers for their input.

Financial support. This open-access publication was funded by Julius-Maximilians-Universität Würzburg.

Review statement. This paper was edited by Becky Briant and reviewed by two anonymous referees.
References

Bohms, I.: Säugetiere in der altägyptischen Literatur, Ägyptologie 2, Lit-Verlag, Berlin, Münster, 2013.

Boreik, M., Gabolde, L., and Graham A.: Karnak's quaysides: evolution of the embankments from the Eighteenth Dynasty to the Graeco-Roman Period, in: The Nile: natural and cultural landscape in Egypt, edited by: Willems, H. and Dahms, J.-M., transcript, Bielefeld, 97-144, 2017.

Cordoba, C.: Geoarchaeology, The Human-Environmental Approach, I. B. Tauris, London, New York, Oxford, New Delhi, Sydney, 2020.

Darnell, J. C.: Opet festival, in: UCLA Encyclopedia of Egyptology online (1.1), edited by: Dieleman, J. and Wendrich, W., available at: https://escholarship.org/uc/item/4739r3fr (last access: 27 June 2020), 2010.

David, B. and Thomas, J.: Landscape archaeology: introduction, in: Handbook of landscape archaeology, edited by: David, B. and Thomas, J., Routledge, New York, 27-43, 2016.

De Wit, C.: Le rôle et le sens du lion dans l'Égypte ancienne, E.J. Brill, Leiden, 1951.

El-Sawi, A.: Preliminary report on Tell Basta excavations, Seasons 1969, 1970, 1971, Zeitschrift für Ägyptische Sprache und Altertumskunde, 104, 127-131, 1977.

El-Sayed, R.: La déesse Neith de Saïs, BdE 86, Institut français d'Archéologie orientale, Le Caire,1982 (in French).

Faltings, D., Ballet, P., Förster, F., French, P., Ihde, C., Sahlmann, H., Thomalsky, J., Thumshirn, C., and Wodzinska, A.: Zweiter Vorbericht über die Arbeiten in Buto von 1996 bis 1999, Mitteilungen des Deutschen Archäologischen Instituts, Abteilung Kairo, 56, 131-179, 2000 (in German).

Faltings, D.: Recent excavations in Tell El-Fara'in Buto: new finds and their chronological implications, in: Proceedings of the Seventh International Congress of Egyptologists, Cambridge, 3-9 September 1995, edited by: Eyre, C. J., Peeters, Leuven, 365375, 1998 (in German).

Gardiner, A. H.: Horus the Behdetite, Journal of Egyptian Archaeology, 30, 23-60, 1944.

Geßler-Löhr, B.: Die heiligen Seen ägyptischer Tempel: ein Beitrag zur Deutung sakraler Baukunst im alten Ägypten, Hildesheimer Ägyptologische Beiträge, 21, Gerstenberg, Hildesheim, 1983.

Gomaà, F.: Die Besiedlung Ägyptens während des Mittleren Reiches II: Unterägypten und die angrenzenden Gebiete. Beihefte zum Tübinger Atlas des Vorderen Orients, Reihe B (Geisteswissenschaften) 66, Reichert, Wiesbaden, 1987.

Hartung, U., Ballet, P., Effland, A., French, P. G., Hartmann, R., Herbich, T., Hoffmann, H., Hower-Tilmann, E., Kitagawa, C., Kopp, P., Kreibig, W., Lecuyot, G., Lösch, S., Marouard, G., Zink, A., Nerlich, A., and Pithon M.: Tell el-Fara' in - Buto: 10, Vorbericht, Mitteilungen des Deutschen Archäologischen Instituts Kairo, 65, 83-190, 2009 (in German).

Hartung, U.: Recent investigations of Early Dynastic building structures at Tell el-Fara'in/Buto, in: Ancient Egyptian and ancient Near Eastern palaces, volume I: Proceedings of the conference on palaces in ancient Egypt, edited by: Bietak, M. and Prell, Silvia, London, UK, 12-14 June 2013, 101-112, 2018.

Lange, E.: The lioness goddess in the Old Kingdom Nile Delta: a study in local cult topography, in: Sapientia Felicitas: Festschrift für Günter Vittmann zum 29. Februar 2016, edited by: Lippert, 
S. L., Schentuleit, M., and Stadler, M. A., CENiM, 14, 301-324, 2016.

Lange-Athinodorou, E.: Der "Tempel des Hermes" und die Pfeile der Bastet: zur Rekonstruktion der Kultlandschaft von Bubastis, in: En détail - Philologie und Archäologie im Diskurs, edited by: Brose, M., Dils, P., Naether, F., Popko, L., and Raue, D., De Gruyter, Berlin/Boston, Festschrift für Hans-Werner FischerElfert 1, 549-585, https://doi.org/10.1515/9783110629705-025, 2019.

Lange-Athinodorou, E., Abd El-Raouf, A., Ullmann, T., Trappe, J., Meister, J., and Baumhauer, R.: The sacred canals of the temple of Bastet at Bubastis (Egypt): new findings from geomorphological investigations and Electrical Resistivity Tomography (ERT), J. Archaeol. Sci.-Rep., 26, 1-13, https://doi.org/10.1016/j.jasrep.2019.101910, 2019.

Leclant, J. and De Meulenaere, H.: Une statuette égyptienne à Délos, Kêmi 14, 34-42, 1957 (in French).

Leclère, F.: Les villes de Basse Égypte au Ier millénaire av. J.-C.: analyse archéologique et historique de la topographie urbaine, 2 vols. Bibliothèque d'étude 144, Institut français d'archéologie orientale, Le Caire, 2008 (French)

Mariette, A.: Abydos: description des fouilles exécutées sur l'emplacement de cette ville, Librairie A. Franck; Imprimerie nationale, Paris, 1869 (in French).

Meeks, D. : Mythes et légendes du Delta d'après le papyrus Brooklyn 47.218.84, Mémoires publiés par les membres de l'Institut français d'archéologie orientale 125, Institut Français d'Archéologie Orientale, Le Caire, 2006 (in French).

Montet, P.: Le lac sacré de Tanis, Académie des Inscriptions et Belles-Lettres (Extrait des Mémoires de l'Académie, Tome XLIV), Paris, 1966 (in French).

Naville, E: Bubastis (1887-1889), EEF 8, London, 1891.

Nesselrath, H.-G.: Herodot: Historien, Alfred Kröner Verlag, Stuttgart, 2017 (in German).

Petrie, W. M. F.: Koptos, Bernard Quaritch, London, 1896.

Said, R.: The geological evolution of the River Nile, Springer Verlag, New York, Heidelberg, Berlin, 1981.

Said, R.: The river Nile: geology, hydrology and utilization, Pergamon Press, Oxford, New York, Seoul, Tokyo, 1993.

Sauneron, S.: La porte ptolémaïque de l'enceinte de Mout à Karnak, Mémoires publiés par les membres de l'Institut français d'archéologie orientale, 107, Institut français d'archéologie orientale, Cairo, 1983 (French).
Sauneron, S.: Villes et légendes d'Égypte, Bulletin de l'Institut Français d'Archéologie Orientale (BIFAO), Cairo, 62, 33-57, 1964 (in French).

Schorsch, D.: Bastet goes boating, Bulletin of the Egyptological Seminar (BES), 19, 571-584, 2015.

Tillier, A.: Notes sur l'icherou, Égypte Nilotique et Méditerranéenne, 3, 167-176, 2010.

Ullmann, T., Lange-Athinodorou E., Göbel, A., Büdel, C., and Baumhauer, R.: Preliminary results on the paleo-landscape of Tell Basta/Bubastis (eastern Nile delta): an integrated approach combining GIS-based spatial analysis, geophysical and archaeological investigations, Quatern. Int., 511, 185-199, 2019.

van den Brink, E. C. M.: A geo-archaeological survey in the northeastern Nile Delta, Mitteilungen des Deutschen Archäologischen Instituts, Abteilung Kairo, 43, 7-31, 1986.

von der Way, T.: Buto, in: Encyclopedia of the archaeology of ancient Egypt, edited by: Bard, K. and Shubert, S. B., London, 180184, 1999.

Wilson, N. G.: Herodoti Historiae, Oxford University Press, Oxford, 2015.

Wilson, P.: Gateway to the underworld: the cult areas at Sais, Studies in Ancient Egypt and Sudan, 24, 341-364, 2019.

Wilson, P.: The survey of Saïs (Sa el-Hagar) 1997-2002, Egypt Exploration Society, Excavation Memoir 77, Egypt Exploration Society, London, 2006.

Wilson, P.: Sais I: The Ramesside-Third Intermediate Period at Kom Rebwa, Egypt Exploration Society, Excavation Memoir 98, Egypt Exploration Society, London, 2011.

Wunderlich, J.: Untersuchungen zur Entwicklung des westlichen Nildeltas im Holozän, Marburger geographische Schriften, Marburg/Lahn, Germany, 1989.

Wunderlich, J. and Ginau, A.: Paläoumweltwandel im Raum Tell el Fara'in/Buto: Ergebnisse und Perspektiven geoarchäologischer Forschung, Mitteilungen des Deutschen Archäologischen Instituts Kairo, 70-71, 485-497, 2014/2015 (in German).

Yoyotte, J.: Études géographiques, II: les localités méridionales de la région memphite et le "Pehou d'Héracléopolis", Revue d'égyptologie, 14, 75-111, 1962 (in French).

Zecchi, M.: A study of the Egyptian god Osiris Hemag. Archeologia e storia della civiltà egiziana e del vicino Oriente antico Materiali e studi 1, La Mandragora, Imola, 1996. 